\title{
THE STUDY OF ORGANIZATIONAL BEHAVIOR ON FISHERY MANUFACTURE INDUSTRIES EMPLOYEES PERFORMANCES
}

\author{
Agung Wahyu Handaru $\bowtie$, Umi Mardiyati ${ }^{\bowtie}$ \\ Fakultas Ekonomi, Universitas Negeri Jakarta, Jakarta, Indonesia
}

\begin{tabular}{l} 
Info Artikel \\
\hline Sejarah Artikel: \\
Diterima April 2014 \\
Disetujui Juni 2014 \\
Dipublikasikan September 2014 \\
\hline Keywords: \\
Employee Performance; \\
Organizational Culture; \\
Employee Motivation; \\
Employee Satisfaction. \\
\end{tabular}

\begin{abstract}
The purpose of this study was to examine the employee performance of fish-based food processing industries in West Java, which driven by variables of organizational culture, job satisfaction and motivation. The fishing industry in Indonesia has resulted in huge foreign exchange. On the other hand, their products are still poor quality and do not meet export standard. This is likely due to low employee performance. The research object were employees of three fish-based food processing plants. The sample was selected by simple random sampling technique. This study revealed different results from previous studies, that only organizational culture has an effect on employee performance. While job satisfaction and motivation has no effect on performance.
\end{abstract}

\section{STUDI PERILAKU KEORGANISASIAN KINERJA KARYAWAN INDUSTRI PENGOLAHAN IKAN}

\begin{abstract}
Abstrak
Tujuan penelitian ini adalah menguji kinerja karyawan industri pengolahan makanan berbasis ikan di wilayah Jawa Barat, yang dipengaruhi dari variabel budaya organisasi, kepuasan kerja dan motivasi. Industri perikanan di Indonesia telah menghasilkan devisa negara besar. Disisi lain, hasil produknya masih banyak yang belum memenuhi standar ekspor dan bermutu rendah. Hal tersebut kemungkinan dikarenakan kinerja karyawan yang rendah. Objek penelitian ini adalah karyawan dari tiga pabrik pengolahan makanan berbasis ikan. Sampel dipilih dengan teknik simple random sampling. Penelitian ini mengungkapkan hasil yang berbeda dari penelitian sebelumnya. Dari ketiga variabel independen, hanya budaya organisasi yang berpengaruh pada kinerja karyawan. Sedangkan kepuasan kerja dan motivasi tidak berpengaruh.
\end{abstract}

JEL Classification: M0, M5, M54

\footnotetext{
Alamat Korespondensi:

Jl. Rawamangun Muka, Jakarta Timur

E-mail: agung_1178@yahoo.com,umi.mardiyati@gmail.com
} 


\section{INTRODUCTION}

As a country with a very wide sea area reaching about 5.8 million $\mathrm{km}^{2}$ (kkp.go.id, 2013), it has been the duty of Indonesia to become a giant in the fishing industry and other aquatic biota. Indonesian fisheries sector production was recorded to reach 10 million tons in 2010, lost to Peru which reached 14 million tons and is still far from China reached 55 million tons (kkp.go.id, 2013). The complexity of the production and processing of fish and other aquatic biota in Indonesia causes so many sectors that need to be addressed.

As a long production chain, fish processing industry and aquatic biota strongly associated with fishing, feeding, seeds, medicines, land, fuel, capital availability and quality of human resources (Dahuri, 2013). Limited seafood and aquatic biota processing companies are challenges for Indonesian fisheries industry; it totally requires strong support and commitment from the government. When viewed from the value of the trade and export commodities of Indonesian sea, the fishing industry is very promising and has proven to generate substantial foreign exchange. Indonesia has been successfully exporting marine products to various countries such as the United States in the form of canned fish as worth $\$ 143,759,599$, to Japan valued at $\$ 60,328,981$ and to South Korea worth as $\$ 12,754,901$ (FAO, 2013).

From various regions in Indonesia as the center of seafood processing, some of them are located in West Java. The potential commodities of fish and other biota in the region of West Java are quite large, especially processed fish and shrimp products. The area in West Java which has long been a center of fish and shrimp processing is the Cirebon, Kudat, Karawang, Bekasi, Cianjur and Bandung (http://kemenperin.go.id/direktoriperusahaa n?what=udang+beku\&prov=32).

Problems arisen in the sector of employees' performance of fish processing company are the low quality product from that cannot meet the export standards, and frequently some encountered cases of employees who are not aware of and concerned about healthy food processing standards, so that the resulting product cannot be guaranteed on its cleanliness. Proficiency level of performance problems are allegedly caused by several things: 1) the company is managed by traditional culture which tend to not pay attention to the modernization of food processing; (2) the motivation of employees in work is not supported with the policy of the leader that is to encourage employees to be motivated, so that employees work monotonous and just meet routines alone, (3) employee satisfaction in general is relatively low, it is known from some of the information obtained from employees, especially in the production of particularly associated with lower satisfaction to the workers' wages they receive.

In contrast to previous studies that more discussion regarding the achievement of fishing in general, this research focuses on aspects of the contribution of human resources/ employee to produce refined products based on fish catches in some companies. Based on the background described, some possible formulations of the problem are as follows: (1) does the organizational culture affect on employee performance in three fish processing companies in West Java?; (2) does motivation affect on employee performance in three fish processing companies in West Java?; (3) does job satisfaction affect the performance of employees at three fish processing companies in West Java?; (4) how large is the contribution of organizational culture, job satisfaction and motivation on employee performance in three fish processing companies in West Java?

\section{Organizational Culture}

Hofstede (1986) argues that culture is a wide range of interactions of characteristics that affect the habits of groups of people in their environment. Hofstede derives the cultural concept of mental program divided into three levels, namely: (1) the universal level, means 
Agung Wahyu Handaru \& Umi Mardiyati / The Study of Organizational Behavior on ...

mental program shared by all humans. At this mental program level is entirely inherent in human beings; (2) the collective level, means mental programs that is owned by a few, not all humans. At this level is specialized mental program on a group or category and it can be studied; 3 ) the individual level, which is a unique mental program that is owned by only one, but two people will not have exactly the same mental programs. At this level a few of mental program fraction is inherent in human beings, and more can be learned from the people, organizations or other groups.

Based on factor analysis, Hofstede (1986) empirically finds there are four dimensions of mental programs, namely: (a) the difference in power (power distance), is a cultural dimension which indicates the existence of inequality for members who do not have the power in institutions (family, school, and community) or organization (place of work). The power difference varies depending on the social level, education level, and occupation; (b) uncertainty avoidance, a cultural dimension that indicates the nature of society in facing the unstructured, unclear cultural environment, and cannot be foreseen. The society can avoid this uncertainty with technology, law and religion; (c) individuality vs. collectivism, the cultural dimension that indicates the attitude that sees personal interests and family as the main interest or a common interest in a group. This dimension can also occur in the communities and organizations. In organizations where people have Collectivism dimension requires greater emotional dependency compared with people who have a dimension of Individualism; (d). Masculinity vs. feminity, is a cultural dimension which shows that in every society, there are different roles depending on the different types of members. In a masculine society, a man should be more ambitious, like to compete, and boldly stated his opinion, and tend try to achieve material success.

According to Beach (1993) culture is the core of what is considered important in the organization. The definition of organizational culture as quoted from academia.edu (2013) is a system of values that are believed to be shared by members of the organization and distinguishes it from other organizations. Opinions from Robbins (2009), as quoted by academia.edu (2013) suggests that organizational culture that contains certain values will be a guide for the organization's policy in managing employees and consumers. The similar organizational culture is the belief systems and was developed by the organization and become the guide towards the behavior of the organization.

\section{Motivation}

The study of motivation is usually associated with individual needs. Robbins (2009) explains that the needs hierarchy theory of Maslow's can explain the motivations that appear in each individual. Human needs are classified into five hierarchies of needs, namely: Physiological Needs, Safety Needs, Social Needs, Esteem Needs, Self Actualization.

Other experts such as Gatchter and Falk (2000) revealed that the intrinsic and extrinsic motivation together affect the quality of someone's work. The combination of intrinsic and extrinsic an agreement defined and associated with a person's psychology. A person's motivation to work is also influenced by the compensation he gets, whether it would be financial and non-financial compensation. Another opinion expressed by Dessler (2013) suggests that motif is defined as the power contained within the organism pushing to do (driving force) and are interrelated with other factors, both external factors and internal factors.

Motivation of employees according to Mello (2011) is closely related to the corporate strategic planning in compensation, while according to Cascio (2013) employee motivation can be seen from the level of needs. According to McClelland's theory things that motivate a person on the job are (Robbins \& Judge, 2011): Need for achievement or N-Ach; Need for affiliation or N-Aff; Need for power or N-Pow. 
The need for achievement (N-Ach) is the driving force that motivates a person's works spirit. Because of that, N-Ach will encourage someone to develop creativity and mobilize all its capabilities and energy to achieve maximum performance. The need for affiliation (N-Aff) becomes the driving force that will motivate employees works' spirit because everyone wants to be having the feeling of accepted and respected by others in the environment he lives and works. The need for power (N-Pow) will stimulate and motivate employees' morale and mobilizing all its ability to achieve the best power or position

\section{Job Satisfaction}

Robbins (2009) defines job satisfaction as "an individual's general attitude towards his work" in this case is the employees. Employees can assess how satisfied or not satisfied himself with his work. Satisfaction is a feeling of pleasure or relief that a desire has been achieved or fulfilled. According to Dessler (2013), job satisfaction is on how the feelings of employees toward his job. They said that the feeling of the employees toward their works. They also said that these feelings can be "favorable" and "unfavorable" depending on how the employees assess aspects of job satisfaction itself. A sense of satisfaction can be described as a positive emotion that comes or came from what is experienced by a person in his work. In his study, Luthans (2006) stated that there are five factors that influence job satisfaction, namely: the work itself, salary, supervision, promotion opportunities, relationships with fellow workers.

\section{Employee Performance}

Performance comes from the work performance. As noted by Dessler (2013) that the term is derived from job performance or actual performance (honors or true achievements made by someone) that results in quality and quantity of work achieved by an employee in carrying out their duties in accordance with the responsibilities assigned to him. According to Mello (2011), work performance or achievements can be seen from the quality, quantity and timeliness of work or in other words with regard to effectiveness and efficiency. Meanwhile, according to Cascio (2013) the employee's performance is a measure that can be used to specify the comparison results of the implementation of tasks, responsibilities given by the organization at a particular period and the relative can be used to measure job performance or the performance of the organization.

\section{Framework}

Employee's performance as an output of a long and complex process that takes place in and outside the company. Broadly it is influenced by three main factors namely individual psychological factors, management support and organizational factors (Dessler, 2013). This is similar to the performance management model first introduced by Campbell where performance is a function of: (1) declarative knowledge is the employees' knowledge on the matters relating to their jobs; (2) procedural knowledge which implies how employees understand about how to do the task, and (3) the internal motivation that will make employees passionate and persistent in doing their job (Cascio, 2013). If we analyze further, the performance management model consistently contains individual psychological factors (motivation, personality, job satisfaction, and organizational commitment), organizational factors (organizational culture, compensation, and work environment) and management support factors (labor regulations, complexity, duty and style of leadership).

In many studies in various industry sectors, employee's performance is driven by that employee's motivation himself (Pramudyo, 2008; Fahmy, 2009; Widodo, 2010; Ranihusna, 2010; Mamik 2010; Pentury 2010; Holil \& Sriyanto, 2011; Wijaya \& Suhaji, 2013; Sukarani, 
Agung Wahyu Handaru \& Umi Mardiyati / The Study of Organizational Behavior on ...

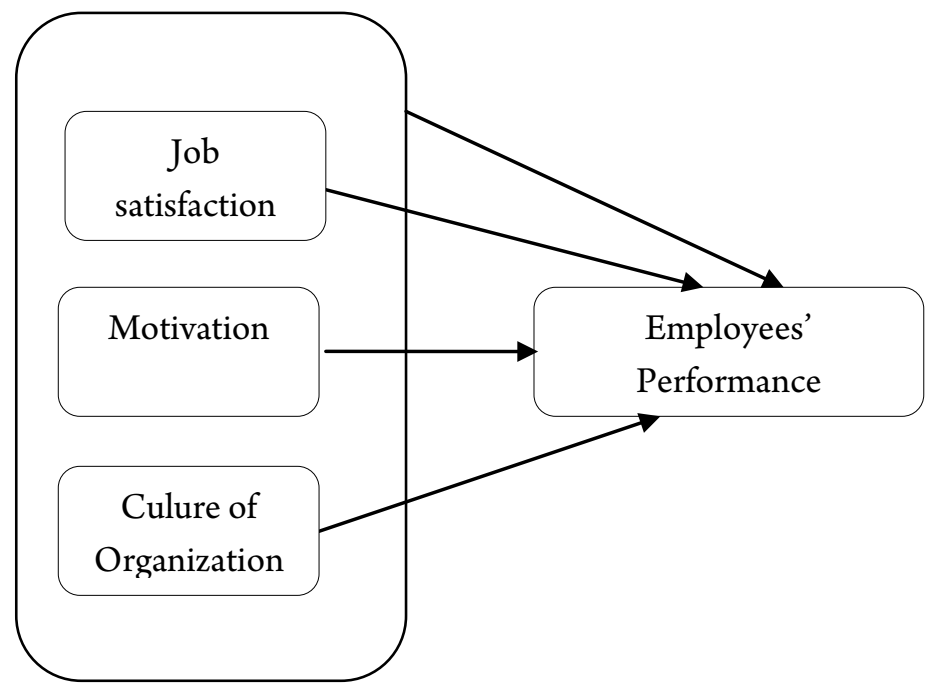

Figure 1. Research Framework

2013). On the other hand the employee's performance can also be achieved through proper management and fair compensation because basically every emmployee is expecting compensation that helps them surviving their life (Rahayu et al., 2013). Research on the influence of leadership styles that have been carried out in various industrial sectors reveals that the performance of employees could not be separated from the style of the leaders in the way they lead the organization (Nugroho, 2006; Mamik, 2010; Nurcahyo, 2012; Rahayu et al., 2013). A leader who, in this case is a manager at the company, plays a very important role in improving the performance of the employees through the implementation of effective leadership, a combination of transactional and transformational styles (Hayward, 2005; Pramudyo, 2008).

Other factors that are also important in the management of an organization's performance is how to create job satisfaction. In various studies and research, job satisfaction is a very important factor in generating high employee's performance (Octaviana, 2011). Linkage achievement of high employee's performance can also be seen from some of the results of other studies that associate performance with working environment. The results show that the performance of employees that occurs at the company has managed to create a comfortable working environment for the employees (Rahayu, 2013; Pramudyo, 2008).

Many studies on the performance of employees affected by organizational commitment (Mamik, 2010; Sudibyo \& Hiskia, 2013). The high commitment of the employees for the organization will tend to produce a high performance of the employees and inside the employees themselves as well as organizational culture that is understood and implemented consistently (Nugroho, 2006; Octaviana, 2011). Based on the literature review and framework that have been stated above, the hypotheses in this study are as follows.

H1: Employees' motivation has positive effect on employees' performance.

$\mathrm{H} 2$ : Employees' satisfaction has positive influence on employees' performance.

H3: Organizational culture has positive effect on employees' performance.

For more details, model construct of employee performance management in this study can be described as Figure 1 .

\section{METHOD}

The research was conducted in three companies located in Bekasi. They are Kerupuk Ikan Irma (Irma fish crackers), in Cianjur 
regency that is Kerupuk Udang Asli Raos (Raos the Original prawn crackers), and in Bandung Regency that is Kerupuk Udang Firman (Firman prawn crackers). Based on the type and nature of the research, as presented above, the method used in this research is a survey research method. This method was chosen because it has characteristics corresponding to the characteristics of this study which are as follows: (1) the goal can be descriptive and also verikative; (2) intended for explanatory or confirmatory, evaluation and prediction; (3) the data collected from a sample that has been determined and research variable data captured using questionnaires as the primary data collection instrument. The total employees of the sample in this study are 145 people from three companies processing fish-based crackers in 3 different cities. In order to determine the size of the sample, the researcher used the Slovin formula.

The sampling method used by the researcher is probability sampling. On the other hand, the probability sampling technique that we used was simple random sampling that is by using lottery. Scale Measurement uses Likert scale in the interval 1-5. Likert in the interval 1-5 for the category of questions with the answers which are strongly disagree with the value of 1 (one) up to answer strongly agree with the value of 5 (five).

\section{Instrument Test}

Valid instrument means the instrument can be used to measure what should be measured. Testing the validity of each item of questionnaire statement will use item analysis which correlates the scores of each item with the total score of each item. The technique that is most widely performed to test the validity is the correlation technique. Reliable instrument is an instrument which is used several times to measure the same object will generate the same data. In this study the reliability test uses Alpha Croncbach's measurement.

\section{RESULTS AND DISCUSSION}

\section{Validity Test Results of Employees' Motivation}

Based on the validity test that has been done, there are some items of questionnaire which must be eliminated because it does not meet the criteria of validity. The full results can be seen in the Table 1. Item number five and six are eiminated on the next test.

Table 1. Validity of employees' motivation

\begin{tabular}{ccc}
\hline Item & $\begin{array}{c}\text { Pearson } \\
\text { correlation sig }(2 \\
\text { tailed })\end{array}$ & Description \\
\hline 1 & 0.00 & Valid \\
2 & 0.00 & Valid \\
3 & 0.03 & Valid \\
4 & 0.00 & Valid \\
5 & 0.142 & Drop \\
6 & 0.068 & Drop \\
7 & 0.00 & Valid \\
8 & 0.00 & Valid \\
\hline
\end{tabular}

Source: data processed (2014)

Validity Test Results of Organizational Culture

Table 2 is the validity test result of the 5 statement items about organizational culture variables which have been given to the respondents. 
Agung Wahyu Handaru \& Umi Mardiyati / The Study of Organizational Behavior on ...

Table 2. Validity of Organizational Culture

\begin{tabular}{ccc}
\hline Item & $\begin{array}{c}\text { Pearson correlation } \\
\mathbf{s i g}(\mathbf{2} \text { tailed })\end{array}$ & Description \\
\hline 1 & 0.00 & Valid \\
2 & 0.00 & Valid \\
3 & 0.03 & Valid \\
4 & 0.00 & Valid \\
5 & 0.00 & Valid \\
\hline Source: data processed (2014)
\end{tabular}

\section{Validity Test Result of Job Satisfaction}

The next table is the result of testing the validity of the 5 statement items of job satisfaction variables consisting of those that have been given to the respondents. The results have been processed can be seen in Table 3 .

Table 3. Validity of Job Satisfaction

\begin{tabular}{ccc}
\hline Item & $\begin{array}{c}\text { Pearson } \\
\text { correlation sig } \\
(\mathbf{2} \text { tailed })\end{array}$ & Description \\
\hline 1 & 0 & Valid \\
2 & 0 & Valid \\
3 & 0 & Valid \\
4 & 0 & Valid \\
5 & 0 & Valid \\
\hline
\end{tabular}

Source: data processed (2014)

\section{Result of Validity Test of Employee's Performance}

The next table is the validity of the test results to the statement items of job satisfaction variables consisting of those that have been given to the respondents. The results have been processed can be seen in Table 4 .
Table 4. Validity of Employee Performance

\begin{tabular}{ccc}
\hline Item & $\begin{array}{c}\text { Pearson } \\
\text { correlation sig } \\
(\mathbf{2} \text { tailed })\end{array}$ & Description \\
\hline 1 & 0.000 & Valid \\
2 & 0.000 & Valid \\
3 & 0.001 & Valid \\
4 & 0.098 & Drop \\
5 & 0.114 & Drop \\
6 & 0.000 & Valid \\
7 & 0.000 & Valid \\
\hline
\end{tabular}

Source: data processed (2014)

Based on test validity through SPSS calculation, there are 2 statement items should be dropped due to the significant value of Pearson correlation which is its 2 tailed is bigger than 0.05 is the item number 4 and 5 .

\section{Reliability Test Results}

Reliability test is used to measure the level of reliability of a questionnaire. A questionnaire said to be reliable is if someone's answers to questions are relatively stable when retested. In this study the reliability test uses Alpha Croncbach's measurement.

\section{Result of Hypothesis Test}

Once the data is confirmed to be used for the regression analysis, the next step is to test the research hypothesis. The results of hypothesis testing can be seen in the Table 6 .

This research uses significance value 0.05 to reject or accept $\mathrm{H}_{0}$ (null hypothesis) and the value of $\mathrm{t}$ table received is 1.982 . As the results contained in the above table, $t$ value for the variable $\mathrm{X}_{1}$ is 0.707 . Because the t value (0.707) $<\mathrm{t}$ table $(1,982)$ and the value of variable 
Table 5. Reliability Test Results

\begin{tabular}{cccc}
\hline No & Variable & Alpha Value & Description \\
\hline 1 & Motivation & 0,000 & Reliable \\
2 & Culture of the organization & 0,000 & Reliable \\
3 & Job Satisfaction & 0,000 & Reliable \\
4 & Employees' Performance & 0,000 & Reliable \\
\hline
\end{tabular}

Source: data processed (2014)

Table 6. Result of Hypothesis Test

Coefficients $^{\mathrm{a}}$

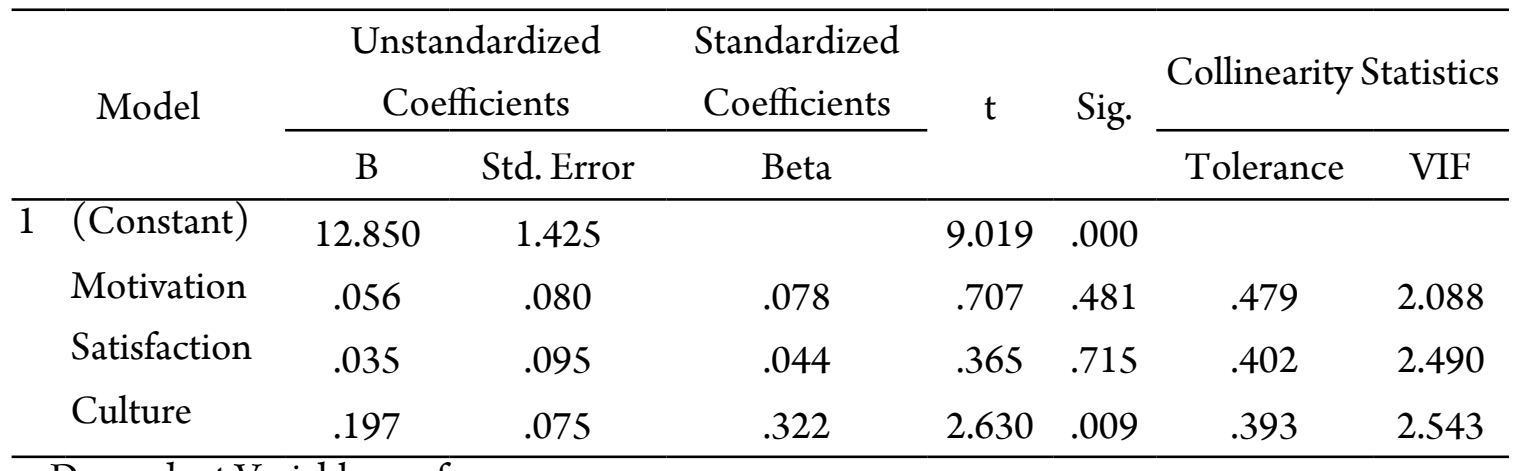

a. Dependent Variable: performance

Source: data processed (2014)

significance Motivation is 0.481 where the score is greater than 0.05 , it means that there is no influence of variable Motivation on Employee Performance. The second result is the $t$ value for the variable $\mathrm{X}_{2}$ is 0,365 . Because the $t$ value $(0.365)<$ t table $(1,982)$ and the value of variable significance Job Satisfaction score is 0.715 which is greater than 0.05 , it means that there is no job satisfaction variables influence the Employee Performance. The third results show $t$ value for the variable $X_{3}$ is 2,630 . Because the $t$ value $(2.630)>t$ table $(1,982)$ and the value of variable significance Organizational Culture is 0.009 where the score is less than 0.05 , it means that there is the influence of organizational culture on employee performance. Based on the above table can also be arranged around the regression equation of the study variables as follows:
$\mathrm{Y}=12850+0.056 \mathrm{X} 1+0.035 \mathrm{X} 2+0.197 \mathrm{X} 3$.

To determine the contribution of all independent variables on the dependent variable, we can use the table below:

From the Table 7, Adjusted $\mathrm{R}^{2}$ value of 0.154 or $15.4 \%$. It shows that $15.4 \%$ Employee Performance formed by Motivation, Job Satisfaction and Organizational Culture, while the remaining $84.6 \%$ is influenced by other variables outside of research.

From the three independent variables learned in this research which are motivation, job satisfaction and organizational culture; it is only the organizational culture which significantly influences the employee performance. The not so significance result from the variable of motivation and job satisfaction toward 
Agung Wahyu Handaru \& Umi Mardiyati / The Study of Organizational Behavior on ...

Table 7. Determination Test Result

\begin{tabular}{cccccc}
\multicolumn{8}{c}{ Model Summary $^{\mathbf{b}}$} \\
\hline Model & $\mathrm{R}$ & R Square & $\begin{array}{c}\text { Adjusted R } \\
\text { Square }\end{array}$ & $\begin{array}{c}\text { Std. Error of } \\
\text { the Estimate }\end{array}$ & Durbin-Watson \\
\hline 1 & $.414^{\mathrm{a}}$ & .171 & .154 & 2.38075 & 1.185 \\
\hline
\end{tabular}

a. Predictors: (Constant), culture, motivation, satisfaction

b. Dependent Variable: performance

Source: data processed (2014)

employee performance is distinguished from the research conducted Nurcahyo (2012), Pratama (2013), Mamik (2010), Octaviana (2011) and Pramudyo (2008).

The findings regarding the lack of effect of motivation on employee performance company shows that motivation is not a major factor for the employees in the three companies. This can be caused by needs factors / need which become the booster of the motivation that has been fulfilled. Needs which are met will no longer be the driving force / motivator, so that no visible influence on the performance significantly. Based on the information and observations made at three locations, some basic needs of the employees are relatively already met, such as the need to eat, drink, rest, shelter, and an adequate salary, at least the salaries of the employees in accordance with the provisions of the minimum wage each city has. Those basic needs of employees which are truly simple can be said to be met by the company, so in terms of motivation, the influence on its performance is not significant anymore.

The second result which differs with the previous researches are that there is no effect upon job satisfaction toward employee work performance. In general of all of those previous researches explain about the influence between job satisfaction with employees' work performance, however in this research occurs reversely. This result is contrary to the research conducted by Pentury (2010), Yuananda, (2013) and Octaviana (2011). The difference in the results of this study with previous studies allegedly because the level of employee satisfaction is at the intermediate level or like always, or in other words, job satisfaction is also not the primary determinant of the employees' performance.

This is in accordance with the statements of several employees who confirmed and mentioned that in general, employees feel there is no problem in their job satisfaction. At first, the allegations about low job satisfaction is because of not optimal policy driven by companies such as the absence of a clear career path, the absence of a policy on employee training, and working uncomfortable conditions. Nevertheless, those three things do not affect the performance of the employees, or in other words the employees do not consider these matters closely related to how they do their daily chores.

This finding explains why employees can still work even if the location of their work is dirty, unhygienic and smelly, the employee considers these conditions is commonplace or ordinary. These factors may be related to the educational level of employees who mostly just graduated from elementary school and middle school, which makes their condition could just let go and do not have the courage to ask for improvement in the condition where they live in.

The third result obtained from this study is that the presence of organizational culture which influencing the performance. This is in line with some researches by Nugroho (2006), Octaviana (2011) and Sudibyo (2013). Organizational culture significantly affects the performance at all three of those companies because the company has been successful 
enough to provide an understanding of the culture of the organization to all employees. Organizational culture that is applied in this company is more focused on cultural kinship and flexibility in work. Almost all employees who were respondents revealed that they feel comfortable and happy with the organizational culture adopted by the three companies. This makes the company is able to survive in the business that they do now.

In relation to the Sundanese culture, "family" culture is a force which capable in creating comfortable working conditions, so that a culture like this is felt most appropriate to be applied in the company. The application of Sundanese culture within the company is very strong within the daily life of the employees, such as the use of Sundanese language as a language of communication that is used by all employees, including management. Besides, ethnicity also creates kinship conditions and strong friendship between employees so that the employees look vibrant and diligent in working.

Other findings from the testing reveals the contribution of all independent variables on the performance of employees is relatively low (15.4\%). The low influence of motivation, job satisfaction and organizational culture on employee performance in this study are suspected for several reasons, namely, the respondent had difficulty in understanding the items of the statement, identification of the main causes of the problem are not appropriate, the tendency of respondents to give feedback is perceived safe for them in filling instrument.

\section{CONCLUSION}

The conclusion of this research are motivation of employees does not influence partially toward employees work performance in three kerupuk companies in three cities of West Java. Organizational culture partially influences toward employees' performance in three kerupuk companies in three cities of West Java. Job satisfaction partially does not affect toward the employees' work performance in three kerupuk companies in three cities of West Java. This finding also give suggestions for fishing process companies.

From the results of the research, it is revealed that those companies do not have any clear career path, therefore the first thing companies must do is to frame career path or the system of career development which is transparent so that is easy to be understood by all of the employees. Conducting a review of salary policy. Gradually, the salaries of employees need to be raised because it is still below the minimum of wage town. Company must immediately improve the working conditions because current state employees assess that the working place is uncomfortable, especially the noise problems and not hygienic production. Gradually and traditionally the company should increase and improve its modern management principles which are suitable to local conditions in order to process more professional food processing in order to increase the performance of the company. Companies need to recruit employees with management or business background to enhance the understanding of the business and its strategies.

For further research, extending the scope of research to expand the research sites in many cities in West Java in order to get better research conclusions, referring that the variable of performance is a complex variable, it is necessary to add other variables outside of this research in order to map out and explain the complexities of employees with better performance. Variables that can be added is the discipline of work, job complexity, emotional intelligence, work stress, leadership style, and can also be controlled with a variable length of service and level of education. It is important to be careful and precise in identifying the determination of the dependent variable and the independent variables in order to obtain good test results. Preparation of instrument items need to consider the conditions and background of the respondents 
Agung Wahyu Handaru \& Umi Mardiyati / The Study of Organizational Behavior on ...

\section{REFERENCES}

Beach, L. R. 1993. Making the Right Decision Organizational Culture, Vision and Planning. Prentice-Hall Inc.

Cascio, W. F. 2013. Managing Human Resources. New York: McGraw-Hill.

Dahuri, R. 2012. Daya Saing Produk Perikanan Indonesia Rendah. Rokhmin Dahuri Information Center, Jakarta.

Dessler, G. 2013. Human Resource Management. Harlow: Pearson Education.

Fahmi,2009.AnalisisPengaruh Gaya Kepemimpinan dan Motivasi Kerja terhadap Kinerja Pegawai SPBU Pandanaran Semarang. Available at: http://www.gunadarma.ac.id/ library/articles/graduate/economy/2009/ Artikel_10205450.pdf.FAO.org/fishery/ statistics/en/2013.

Gatchter, S \& Falk, A. 2000. Work Motivation, Institutions, and Performance. Working Paper. The Hongkong University Of Science And Technology.

Hofstede, G. 1986. Culture's Consequences, International Differences In Work Related Values. London: Sage Publication.

Hayward B., A. 2005. Relationship Between Employee Performance, Leadership and Emotional Intelligence in A South African Parastatal Organisation. Available at: http:// www.actacommercii.co.za/index.php/acta/ article/download/57/57.

Holil, M \& Sriyanto, A. 2011. Pengaruh Motivasi dan Disiplin Kerja terhadap Kinerja Pegawai (Studi Kasus Kantor Pelayanan Pajak Badan Usaha Milik Negara). available at: http://fe.budiluhur.ac.id/wp-content/ uploads/2011/05/pengaruh-motivasi-dandisiplin-kerja-tehadap-kinerja-pegawai-holilsriyanto.pdf

(http://kemenperin.go.id/direktori-perusahaan?w hat=udang+beku\&prov=32).

kkp.go.id/index.php/mobile/2012.

Luthans, F. 2006. Perilaku Organisasi Edisi 10. Yogyakarta: Penerbit Andi.

Mamik. 2010. Pengaruh Gaya Kepemimpinan, Motivasi Kerja, dan Komitmen Organisasi terhadap Kinerja Karyawan. Thesis. Program Pascasarjana Universitas Brawijaya.
Mello, J. A. 2011. Strategic Management of Human Resources. South-Western: Cengage Learning.

Nugroho, R. 2006. Analisis Faktor-Faktor yang Mempengaruhi Kinerja Karyawan (Studi Empiris pada PT. Bank Tabungan Negara (Persero), Cabang Bandung. Available at: http://core.kmi.open.ac.uk/download/ pdf/11718395.pdf.

Nurcahyo, A. 2012. Analisis Variabel-Variabel yang Mempengaruhi Kinerja Karyawan pada CV. Eka Utama Karya Samarinda. Available at: http://karyailmiah.polnes.ac.id/index. php/eksis/terbitan-jurnal/vol-08-nomor-1agustus-2012/175-analisis-variabel-variabelyang-mempengaruhi-kinerja-karyawanpada-cv-eka-utama-karya-samarinda.

Octaviana, N. 2011. Pengaruh Budaya Organisasi terhadap Motivasi dan Kepuasan Kerja Serta Kinerja Karyawan (Pada PT. Mirota Kampus Di Yogyakarta). available at: http:// repository.upnyk.ac.id/1414/1/pengaruh_ budaya_organisasi.pdf.

Pramudyo, A. 2008. Analisis Faktor-Faktor yang Mempengaruhi Kinerja Dosen Negeri Dipekerjakan pada Kopertis Wilayah V Yogyakarta. Available at: http://jurnal. umy.ac.id/files/journals/8/articles/1456/ submission/review/1456-2103-1-RV.doc.

Pratama, R. 2013. Pengaruh Motivasi dan Kepuasan Kerja terhadap Kinerja Karyawan Hotel Mutiara Merdeka Pekanbaru. Available at: http://repository.unri.ac.id/xmlui/ bitstream/handle/123456789/707/ JURNAL\%20RADITYA\%20PRATAMA. pdf?sequence $=1$.

Pentury, G. M. 2010. Analisis Kinerja,Variabel Anteseden, dan Dampaknya pada Kepuasan Kerja (Studi Pada Manajer Bank BRI Di Malang). Available at: https://docs.google. com/document/d/1P7w3fRlBcu9EkOnfBl $M R p Y k G d f V h M l A B$ a BdBqqME/ preview? pli=1.

Rahayu V., T., Ariyani, V \& Kurniawan, S. 2013. Pengaruh Kepemimpinan, Lingkungan Kerja Fisik, dan Kompensasi terhadap Kinerja Karyawan Di PT. PLN Cabang Madiun. Available at: http://jurnal.umrah. ac.id/wp-content/uploads/2013/08/AtikaPrimayanti-090462201048.pdf. 
Ranihusna, D. 2010. Efek Rantai Motivasi pada Kinerja. Jurnal Dinamika Manajemen. 1 (2): 90-103.

Robbins, S. P. 2009. Organizational Behavior. Mary K. Coulter, Management, 5e. New Jersey: Prentice Hall.

Robbins, S \& Judge, T. 2011. Organizational behavior. 14th edition. New Jersey: Prentice Hall.

Sudibyo Y., A \& Hiskia R., F. 2013. The Influences of Workplace Spirituality, Organizational Factors, and Cultural Factors on Employees Performance through Organizational Commitment. Available at: http://www. caal-inteduorg.com/ibea2013/caal_ibea_ proceeding.php.

Sukarani. 2013. Pengaruh Motivasi dan Disiplin Kerja terhadap Kinerja Karyawan PT Columbindo Perdana Cabang Purworejo. Jurnal Oikonomia. 1 (2).
Widodo. 2010. Efek Moderasi Kerja Cerdas pada Pengaruh Kompetensi, Reward, Motovasi terhadap Kinerja. Jurnal Dinamika Manajemen. 1 (2): 125-136.

Wijaya, A \& Suhaji. 2011. Pengaruh Kemampuan dan Motivasi terhadap Kinerja Karyawan. Availableat: http://jurnal.widyamanggala.ac.id/ index.php/wmkeb/article/download/10/7.

Yuananda. 2013. Pengaruh Lingkungan Kerja terhadap Kepuasan Kerja dan Kinerja Karyawan (Studi Pada Perum Jasa Tirta I Malang Bagian Laboratorium Kualitas Air). Available at: http://www.jimfeb.ub.ac.id/ index.php/jimfeb/article/viewFile/173/136. 